\title{
Comparative experiment study on the effect of red beds slope supported by geotextile bag and gabion
}

\author{
Qiao ZHANG ${ }^{1, a}$, Ming-hui WANG ${ }^{1, b^{*}}$ \\ ${ }^{1}$ Chongqing-Guizhou Railway Co., Ltd., Chongqing City, PRC \\ a23590194@qq.com, b18623151583@126.com
}

Key words: slope protection; geotextile bag; gabion; displacement; bearing capacity

Abstract: Slope supported by gabion and geotextile bag both have a high supporting strength, and with local materials, convenient construction, adaptability, environmental protection, low noise, low engineering cost and other advantages. So, it has a rapid development and wide application. To achieve supporting and retaining structure of a red beds slope to effectively play the role of protection, convenient construction and reduce project cost. Under the same conditions of indoor model, a comparative analysis of the natural slope model without shoring, model supported by geotextile or gabion is carried out. Obtain a conclusion that the protective effect of the gabion is better, specific suggestions on the suitability and construction of the supporting structure of the gabion are put forward.

\section{Introduction}

In the red beds slope control techniques, supported by gabion and geotextile bag both have a high supporting strength, and with local materials, convenient construction, adaptability, environmental protection, low noise, low engineering cost and other advantages ${ }^{[1,2]}$. it has a rapid development ${ }^{[3,4]}$. Gabion retaining wall is widely used in slope support ${ }^{[5]}$, such as applied to the Wu-Shilu road by CAI Hejun ${ }^{[6]}$, also the gabion retaining wall is applied to the highway slope, and so on. In recent years, the application of the technology of the soil in the foundation reinforcement and achieved good results by Liu Sihong ${ }^{[7-11]}$, Wang Yanqiao ${ }^{[12]}$, etc. But in the application of the slope support is not much. To the problem of instability of the red beds slope, plan to adopt the gabion or geotextile. In order to achieve better control effect, the mechanical properties were studied through the indoor model test, compared supporting effect, achieving the purpose of guiding engineering practice.

\section{Experiment materials}

\section{Slope soil}

Common red beds soil is used in slope. The basic physical and mechanical properties of the slope are shown in Table 1.

Table 1 The basic physical and mechanical properties of the red beds soil

\begin{tabular}{ccccc}
\hline $\begin{array}{r}\text { Density } \\
\left(\mathrm{g} / \mathrm{cm}^{3}\right)\end{array}$ & $\begin{array}{c}\text { Moisture content } \\
(\%)\end{array}$ & Compressibility & $\begin{array}{c}\text { Cohesion } \\
(\mathrm{kPa})\end{array}$ & $\begin{array}{c}\text { Internal friction angle } \\
\left({ }^{\circ}\right)\end{array}$ \\
\hline 1.8 & 11 & 0.28 & 8.5 & 28.6 \\
\hline
\end{tabular}




\section{Geotextile bag}

Geotextile bag doped with an appropriate amount of anti-aging UV stabilizers polypropylene (PP) materials, black bags with dimensions of $320 \times 120 \times 56 \mathrm{~mm} 3$, connect buckle using reverse bayonet type.

\section{Gabion}

The gabion is made of rectangular galvanized iron wire material. Its size is $2 \times 1 \times 0.5 \mathrm{~m} 3$ and the grid size is $100 \mathrm{~mm} \times 80 \mathrm{~mm}$. Filled with test abandoned concrete block.

\section{Experiment scheme and method}

\section{Model design}

The purpose of the slope laboratory model test is to verify the effect of the gabion and the geotextile bag on the protect and reinforce to the slope. Under the same conditions that slope ratio $1: 0.5$, model height is $100 \mathrm{~cm}$, unified loading in the wall, loading width is $20 \mathrm{~cm}$. Multi-stage loading using the oil pressure jack, the loading rate is $0.05 \mathrm{MPa} / \mathrm{s}$. The displacement and failure load of the slope of the three cases are compared. The design of the laboratory model test is shown in Fig.1.

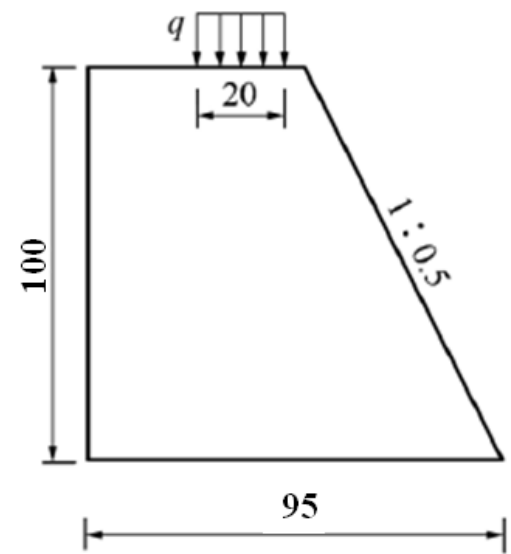

(a) natural slope model without shoring

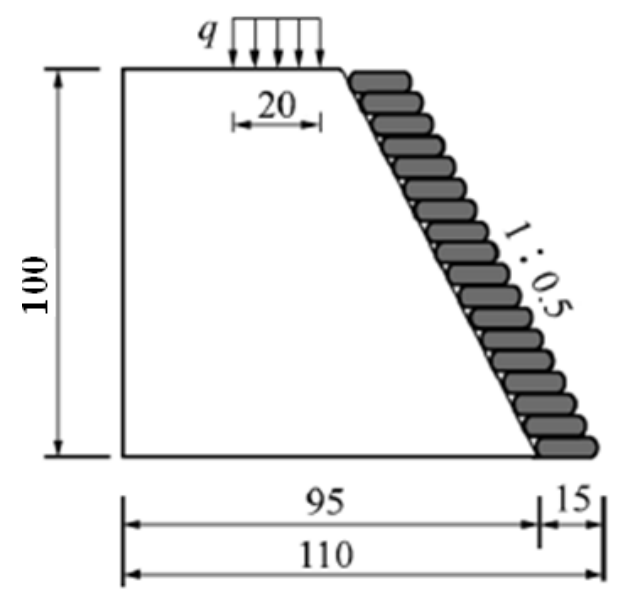

(b) model supported by geotextile bag

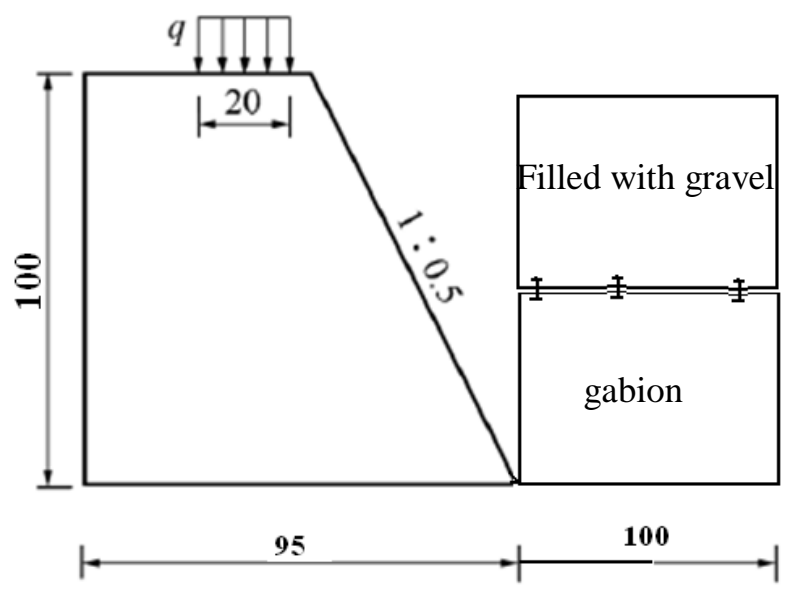

(c) model supported by gabion

Fig.1 laboratory model of slope support 


\section{Test content and test components layout}

The main content of the laboratory model test are vertical, horizontal displacement and ultimate bearing capacity of slope top. Dial indicator used to measuring displacement, ultimate bearing capacity of slope top directly displayed on servo-hydraulic loading system.

\section{Supporting structure masonry \\ Geotextile bag masonry}

Geotextile bag must to be fill compacted, sealing bag along the line of the slide, control the height of the bag after filling is about $0.2 \mathrm{~m}$. If the particulate of soil is too small should be properly mixed with sand, maintaining d95>0.21 mm and the water content of fine grained soil in the bag is suitable for the optimal water content $5 \%$. If excessive moisture, it can be mixed with ash. Masonry, connecting the upper and lower geotextile bags buckle and should criss-cross or " $\mathrm{T}$ " shaped Bonding, the masonry method shown in Fig.2.

\section{Gabion masonry}

First, the folded gabion placed flat on the ground and the front and rear panels, floor and bulkhead erected a box shape. Upper and lower corners of adjacent cage group with a combination of double-stranded wire connection. Up and down the border, or line with a diameter greater than 3 $\mathrm{mm}$ galvanized wire line double strand lashing per $20 \mathrm{~cm}$, so that the whole structure of the piece. The filling height of gabion is $25 \mathrm{~cm}$, tamping, and the surface is flat and smooth. The small stone grout should be mainly in the interior, exposed surface is not suitable for small stone. The masonry method is same as geotextile bag, the method shown in Fig.3.

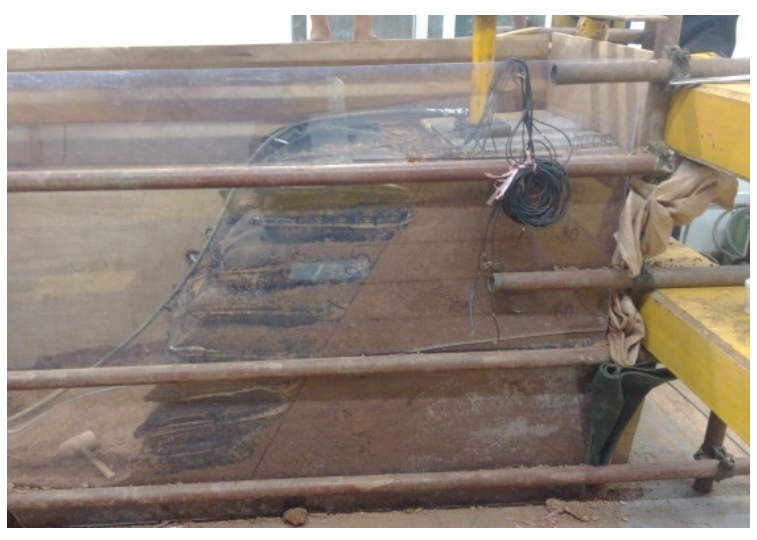

Fig.2 Geotextile bag masonry

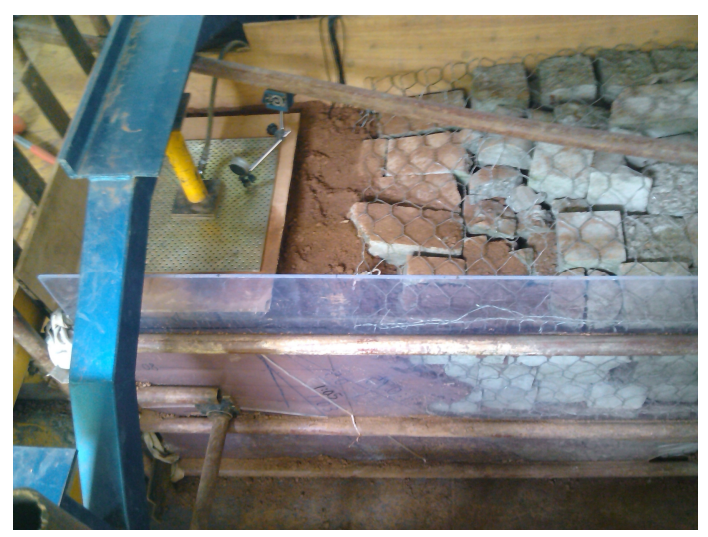

Fig.3 Gabion masonry

\section{Test results and analysis}

Under the same conditions that slope ratio 1:0.5, the vertical, horizontal displacement and ultimate bearing capacity when the through cracks appeared of the natural slope model without shoring, model supported by geotextile or gabion is tested separately.

During the experiment, every $10 \mathrm{~min}$ recording a servo-hydraulic system pressure gauge readings and the corresponding displacement of the top of the slope. When pressure is basically unchanged or has been reduced and the displacement increases rapidly on the slope top, slope failure, then the pressure on the top of slope called the failure loads. The test results are shown in Table 2. 
Table 2 Model test results under different support conditions

\begin{tabular}{ccccc}
\hline $\begin{array}{c}\text { Supporting } \\
\text { condition }\end{array}$ & $\begin{array}{c}\text { Maximum } \\
\text { horizontal } \\
\text { displacement on } \\
\text { slope top (mm) }\end{array}$ & $\begin{array}{c}\text { Maximum vertical } \\
\text { displacement on } \\
\text { slope top (mm) }\end{array}$ & $\begin{array}{c}\text { Vertical } \\
\text { maximum load } \\
\text { (MPa) }\end{array}$ & $\begin{array}{c}\text { Distance from the } \\
\text { rupture plane to } \\
\text { slope top (cm) }\end{array}$ \\
\hline $\begin{array}{c}\text { Natural slope } \\
\text { Geotextile } \\
\text { bag }\end{array}$ & 9.208 & 30.960 & 10 & 50.2 \\
Gabion & 6.890 & 32.995 & 22 & 72.5 \\
\hline
\end{tabular}

From table 2, can see that.

(1) Under the same slope ratio, natural slope limit bearing capacity is $10 \mathrm{MPa}$, geotextile bag supporting is $22 \mathrm{MPa}$, gabion supporting is $35 \mathrm{MPa}$. The slope stability are greatly improved by using geotextile bag or gabion, expecially gabion supporting.

(2) Under the same slope ratio, natural slope top horizontal displacement is $9.208 \mathrm{~mm}$, geotextile bag supporting is $6.890 \mathrm{~mm}$, there is not horizontal displacement of the gabion supporting. gabion supporting large vertical displacement is caused by soil settlement. That is the gabion has stronger ability to resist the horizontal force, supporting effect is better.

(3) Under the same slope ratio, the distance between slope rupture surface increase, then the rupture surface growth, indicating that the slope is more stable and difficult to destroy by using geotextile supporting and gabion supporting, the latter supporting effect is better.

\section{Conclusion}

Through the laboratory model test about natural slope model without shoring, model supported by geotextile bag or gabion, comparatively analyze their horizontal displacement, vertical displacement, ultimate bearing capacity and the failure mode of the slope. analyze the influence of supporting form on the slope reinforcement effect.

The results show that the geotextile bag and gabion have good retaining effect on red bed region slope, and the latter is better, but it is restricted by the site filling material. According to different site conditions, the choice of red bed region slope protection measures followed.

(1) If the stone is enough, use gabion supporting, otherwise, use geotextile bag supporting.

(2) When the slope ratio is greater than 1:0.3, use gabion supporting, otherwise, geotextile bag supporting.

(3) When the slope has weak layer, either the gabion or geotextile bag supporting is ok. but if the slope is too steep, use gabion supporting.

(4) If use geotextile bag supporting, each level of support height should not exceed $3 \mathrm{~m}$, if use gabion supporting, each level of support height should not exceed $5 \mathrm{~m}$, at the same time, should pay attention to the whole connection of the gabion and the geotextile bag.

\section{References}

[1] SU Jie, ZHOU Cheng, et al. Numerical simulation of flexible gabion arch dam to prevent and control debris flow blocks[J]. Chinese Journal of Geotechnical Engineering, 2015, 37(2): 269-275. (in Chinese) 
[2] MATSUOKA H , LIU S H. A new earth reinforcement method using soilbags[M]. [S.1.] :

Taylor and Francis , $2006: 55-61$.

[3] CHEN R H, CHIU Y M. Model tests of geocell retaining structures[J]. Geotextiles and Geomembranes , 2008 , 26(1): 56-70.

[4] MENG Yun-wei, CHAI He-jun, et al. Mesomechanical research on gabion retaining wall with particle flow code[J]. Rock and Soil Mechanics, 2010, 31(8): 2677-2681+2688. (in Chinese)

[5] Officine Maccaferri. Flexible gabion structures in earth retaining works [M]. U.S.A.: [s.n], 1987.

[6] CHAI He-jun, HU Yuan-xin, et al. Application of Gabion Retaining Wall in Wuxi-Shiyan Highway[J]. Journal of Highway and Transportation Research and Development, 2007, 24(9): 19-23. (in Chinese)

[7] LIU Sihong, WANG Yisen. Reinforcement mechanism of soilbags and its applications[J]. Geotechnical Engineering Technique , 2007 , 21(5) : 221-225.(in Chinese)

[8] LIU Sihong, MATSUOKA H. A new earth reinforcement method by soilbags[J]. Rock and Soil Mechanics , 2007 , 28(8) : 1665-1670.(in Chinese)

[9] LIU Si-hong, WANG Yi-shen. Reinforcement mechanism of soilbags and its applications[J]. Journal of Hydraulic Engineering, 2007, 38(S0): 644-648.(in Chinese)

[10] LIU Si-hong, BAI Fu-qing, WANG Yi-shen. Experimental study on wetting induced deformation and strength characteristics of soilbag filled with expansive soil[J].South to North Water Transfers and Water Science \& Technology, 2009, 7(6): 54-58. (in Chinese)

[11] LIU Si-hong, WANG Liu-jiang, LI Zhuo. Numerical simulation of in-situ loading tests on a soilbag-reinforced soft foundation[J]. Advances in Science and Technology of Water Resources, 2012, 32(1): 78-82. (in Chinese)

[12] WANG Yanqiao, LIU Sihong, et al. MODEL TEST OF SANDY SOIL SLOPE REINFORCED BY SOILBAGS AND UPPER-BOUND SOLUTION [J]. Chinese Journal of Rock Mechanics and Engineering, 2009, 28(sup2): 4006-4013. (in Chinese) 